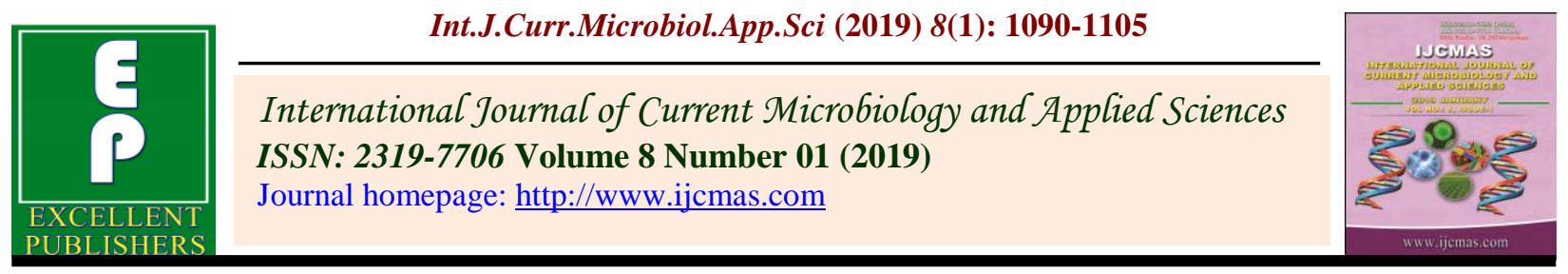

Original Research Article

https://doi.org/10.20546/ijcmas.2019.801.118

\title{
Influence of Weather Variability, Plant Density and Fertilizer Regimes on Growth and Yield of Cotton under Rainfed Condition
}

\author{
M.M. Ganvir ${ }^{1}$, A.P. Karunakar ${ }^{1}$, V.M. Bhale ${ }^{1}$, M.B. Nagdeve ${ }^{2}$, \\ V.V. Gabhane ${ }^{2}$ and S.S. Wanjari ${ }^{1}$ \\ ${ }^{I}$ Department of Agronomy, Dr. PDKV, Akola, India \\ ${ }^{2}$ AICRP for Dryland Agriculture, Dr. PDKV, Akola, India \\ *Corresponding author
}

A B S T R A C T

Keywords

Cotton, Fertilizer regimes, Plant density, Seed cotton yield, Stalk yield, Weather variability

Article Info

Accepted:

10 December 2018

Available Online:

10 January 2019

\begin{abstract}
A field experiment was carried out during kharif seasons of 2013-14 and 2014-15 at Research farm of AICRP for Dryland Agriculture, Dr. PDKV, Akola to study the growth and yield of cotton under weather variability, plant density and fertilizer regimes under rainfed condition. The experimental was laid out in split plot design with eighteen treatment combinations in three replications. The soil of experiment was Inceptisols clayey in texture having $\mathrm{pH} \mathrm{8.1,} \mathrm{organic} \mathrm{carbon}$ $(0.54 \%)$, available nitrogen (187.3 kg ha-1), available phosphorus (14.8 kg ha-1) and available potassium (316.0 kg ha-1). The pooled results indicated that seed cotton and stalk yield was significantly higher in monsoon sowing, 200\% plant density and in $200 \%$ RDF.
\end{abstract}

\section{Introduction}

Cotton is an important cash crop of Vidarbha region. In Maharashtra state, the area under this crop is 41.98 lakh ha and yielding 85.00 lakh bales next to Gujarat (104.00 lakh bales) with average productivity of $344.0 \mathrm{~kg}$ lint $\mathrm{ha}^{-1}$ (Anonymous, 2018). Vidarbha is a major cotton growing region having an area of 15.08 lakh ha with average productivity of $533.0 \mathrm{~kg}$ lint $\mathrm{ha}^{-1}$ (Anonymous, 2017). In Vidarbha region of Maharashtra, cotton is grown predominantly as a rainfed crop. As such in
Vidarbha region about 87 per cent cultivable land is under rainfed farming. Weather plays an important role in rainfed agricultural production. Agronomic strategies to cope with changing weather are available but not fully explored, and have more emphasis in view of the happening issue of climate change impacts reportedly inducing regional variability and uncertainty of rainfall affecting agricultural production. As such management of rainfed cotton production system is challenging and is a high-risk enterprise given the uncertainty of rainfall in its onset and distribution during the 
growing season. In fact monsoon onset behaviour has direct bearing on the acreage of cotton crop as timely onset with significant amount of sowing rains favours timely sowing of the crop within the normal sowing window. As often observed in recent years, late monsoon onset and/or non-receipt of significant pre-soaking rains pushes cotton crop beyond its normal sowing window (June 30) and cotton growers face a problem of low cotton yield in late planting. This has also resulted in decline in cotton sowing and its stagnating rate of growth. In order to cope with the decline in cotton sowing and its stagnating rate of growth, the strategy is to increase production per unit area rather than increase the absolute area of cotton production. In many countries, narrow row plantings have been adopted after showing improvement in cotton productivity (Ali et al., 2010). Fertilizer management along with high density planting is important because fertilizer requirement is most likely to be higher under HDP (Jost and Cothren, 2000). Hence, within the varying rainfed environment, the potential effects of adopting higher plant population with compatible NPK fertilizer management (as fertilizer requirement is most likely to be higher under HDP) offer a good opportunity to boost the crop output. The aim of the experiment was to study the growth and yield of cotton under weather variability, plant density and fertilizer regimes under rainfed condition.

\section{Materials and Methods}

The experiment was carried out at Research farm of All India Coordinated Research Project for Dryland Agriculture, Dr. Panjabrao Deshmukh Krishi Vidyapeeth, Akola Maharashtra during kharif seasons of 2013-14 and 2014-15. The soil of experimental site was medium black (Inceptisols), clayey in texture, slightly alkaline in reaction $(\mathrm{pH} 8.1)$, organic carbon $(0.54 \%)$, available nitrogen $(187.3 \mathrm{~kg}$ $\left.\mathrm{ha}^{-1}\right)$ and available phosphorus (14.8 $\mathrm{kg} \mathrm{ha}^{-1}$ ) whereas available potassium (316.0 kg ha-1). The experiment was laid out in split plot design with eighteen treatment combinations in three replications. The treatments included weather variability in factor A (two sowing times $\mathrm{S}_{1^{-}}$monsoon sowing and $\mathrm{S}_{2^{-}}$late sowing) and plant density in factor $\mathrm{B}\left(\mathrm{P}_{1}-60\right.$ $\mathrm{cm} \times 30 \mathrm{~cm}, 1.11$ lakh, $\mathrm{P}_{2^{-}} 60 \mathrm{~cm} \times 10 \mathrm{~cm}$, 1.66 lakh and $\mathrm{P}_{3^{-}} 45 \mathrm{~cm} \mathrm{x} 10 \mathrm{~cm}, 2.22$ lakh) as main plot treatments with three fertilizer regimes in factor $\mathrm{C}\left(\mathrm{F}_{1}-100 \% \mathrm{RDF}, 60: 30: 30\right.$, $\mathrm{F}_{2}-150 \%$ RDF, 90:45:45, and $\mathrm{F}_{3}-200 \%$ RDF, 120:60:60 NPK $\mathrm{kg} \mathrm{ha} \mathrm{ha}^{-1}$ as sub plot treatments. The $\mathrm{N}, \mathrm{P}$ and $\mathrm{K}$ were applied through urea, single super phosphate and muriate of potash respectively. Half $\mathrm{N}$, full $\mathrm{P}$ and full $\mathrm{K}$ was applied at the time of sowing and half $\mathrm{N}$ at 30 days after emergence (DAE). Cotton crop variety used was AKH 081. Rainfall during the kharif seasons was $821.7 \mathrm{~mm}$ and $570.1 \mathrm{~mm}$ during 2013-14 and 2014-15 respectively as against normal rainfall of $688.0 \mathrm{~mm}$.

\section{Results and Discussion}

\section{Growth studies}

\section{Plant height}

Plant height was significantly influenced throughout the crop growth period by weather variability (Table 1). The maximum plant height was recorded with monsoon sowing whereas late sowing produced least plant height at all the stages of crop growth during both the season of experimentation. Increased plant height in monsoon sowing might be due to enhanced vegetative development of crop due to the favourable weather condition, particularly favourable rainfall and hence soil moisture regime throughout the growing period. Similar results regarding difference in plant height were reported by Hallikeri et al., (2009), Pettigrew and Meredith (2009), 
Hebbar et al., (2010), Ban et al., (2015) and Pinky Patel et al., (2016).

During 2013-14 differences due to population density on plant height was found to be significant at all growth stages except at maturity. At 30 DAE, higher plant height was recorded in $45 \times 10 \mathrm{~cm}\left(2,22,222\right.$ plants $\left.\mathrm{ha}^{-1}\right)$ being at par with $60 \times 10 \mathrm{~cm}(1,66,666$ plants $\left.\mathrm{ha}^{-1}\right)$. Least plant height was recorded in $60 \mathrm{X}$ $15 \mathrm{~cm}$ spaced $\left(1,11,111\right.$ plants $\left.^{-1} \mathrm{a}^{-1}\right)$ population density. During 60 to 120 DAE significantly highest plant height was observed in plant density of $45 \times 10 \mathrm{~cm}\left(2,22,222\right.$ plants $\left.^{-1}\right)$. Plant height did not vary significantly under different plant densities at maturity stage.

During 2014-15, significantly higher plant height was recorded with population density at $45 \times 10 \mathrm{~cm}\left(2,22,222\right.$ plants ha $\left.^{-1}\right)$ at 60 and 90 DAE, which was at par with $60 \times 10 \mathrm{~cm}$ $\left(1,66,666\right.$ plants $\left.\mathrm{ha}^{-1}\right)$ plant density. Significant influence on plant height due to plant density was not observed at 30 DAE, 120 DAE and at maturity. These results are conformity with Hake et al., (1991) according to whom cotton seedlings tend to grow taller in thick stand. As the season progresses, plant height in thick stand tend to lag behind than that of thin stand and at harvest high density stands have the lowest average plant height. Ruth Kaggwa Asiimwe et al., (2013) observed that plant spacing directly influenced soil moisture extraction, light interception, humidity and wind movement. Zhang et al., (2014) also observed decreased cotton plant height with increased plant density.

Increase in the fertilizer regime increased the plant height progressively during both season of the experimentation. Plant height significantly increased with increase in fertilizer regimes. During 2013-14, fertilizer regime of 120:60:60 NPK kg ha ${ }^{-1}$ recorded significantly higher plant height however on par with 90:45:45 NPK kg ha ${ }^{-1}$ fertilizer regime at all stages of observation. During 2014-15, fertilizer regime of 120:60:60 NPK $\mathrm{kg} \mathrm{ha}{ }^{-1}$ recorded significantly higher plant height being at par with 90:45:45 NPK kg ha fertilizer regime at 30,120 and at maturity stage. Fertilizer regime of 60:30:30 NPK kg $\mathrm{ha}^{-1}$ recorded the least plant height during both the season. Earlier, Singh et al., $\left(2012^{\mathrm{b}}\right)$ indicated that the progressive improvement in plant height with every successive increase in nutrient levels. Singh et al., $\left(2012^{\mathrm{a}}\right)$ observed that application of $150 \%$ RDF recorded significantly higher plant height plant ${ }^{-1}$ than $100 \%$ RDF and $75 \%$ RDF but at par with the $125 \%$ RDF.

The treatment combination $\mathrm{S}_{1} \mathrm{P}_{3}$ (monsoon sowing with 2,22,222 plants $\mathrm{ha}^{-1}$ ) recorded significantly highest plant height than rest of the treatment combinations at $30 \mathrm{DAE}$ during 2013-14 (Table 2).

The treatment combination of $\mathrm{P}_{3} \mathrm{~F}_{3}$ i.e. $45 \times 10$ cm $\left(2,22,222\right.$ plants ha $\left.^{-1}\right)$ with 120:60:60 NPK $\mathrm{kg} \mathrm{ha}^{-1}$ fertilizer regime recorded significantly highest plant height than other treatment combinations (Table 3).

\section{Sympodial branches}

Weather variability significantly influenced the number of sympodial branches plant ${ }^{-1}$ from 60 DAE to harvest stage of crop (Table 4). Monsoon sown crop produced significantly higher sympodial branches plant ${ }^{-1}$ than late sown crop. Increased sympodial branches plant $^{-1}$ in June sown crop showed the greater encouragement for reproductive phase that ultimately reflected on promotion of yield and yield components. These findings were supported by the results of Hebber et al., (2002), Dong et al., (2006) and Hallikeri et al., (2009)

During 2013-14 season, sympodial branches plant $^{-1}$ was significantly higher in plant 
density of $60 \times 15 \mathrm{~cm}\left(1,11,111\right.$ plant $\left.\mathrm{ha}^{-1}\right)$ than high plant density of $60 \times 10 \mathrm{~cm}$ $\left(1,66,666\right.$ plant $\left.\mathrm{ha}^{-1}\right)$ and $45 \mathrm{X} 10 \mathrm{~cm}$ $\left(2,22,222\right.$ plant $\left.\mathrm{ha}^{-1}\right)$ at 60 DAE. However, from 90 DAE to harvest stage it proved on par with population density of $1,66,666$ plant $\mathrm{ha}^{-1}$ but remained significantly superior to population density of 2,22,222 plant $\mathrm{ha}^{-1}$. During 2014-15 season also population density of 111111 plant $\mathrm{ha}^{-1}$, being at par with population density of 166666 plant ha $^{-1}$ was significantly superior to 222222 plant $\mathrm{ha}^{-1}$ population density. This shows greater encouragement for reproductive growth in individual plant under lower population density. Under high density planting there may be excess competition for photoassimilates needed for reproductive development. Stephenson et al., (2011) revealed that number of sympodial branches increased with decreasing plant density. Similar results were also reported by Deotalu et al., (2013) and Jahedi et al., (2013).

Different fertilizer regimes significantly influenced the sympodial branches plant ${ }^{-1}$. During 2013-14, fertilizer regime of 120:60:60 NPK $\mathrm{kg} \mathrm{ha}^{-1}$ recorded highest number of sympodial branches plant $^{-1}$, however it was statistically at par with 90:60:60 NPK kg ha ${ }^{-1}$ and significantly more over 60:30:30 NPK kg $\mathrm{ha}^{-1}$. Similar trend prevailed during 2014-15, except that fertilizer regime of 120:60:60 NPK $\mathrm{kg} \mathrm{ha}^{-1}$ was also statistically superior 90:60:60 NPK kg ha ${ }^{-1}$ at 60 and 120 DAE. Increase in fertilizer application had improved nutrient intake in cotton hybrids which in turn might have increased cell division and consequently production of sympodia plant ${ }^{-1}$. Results were conformity with Bhalerao et al., (2007) and Basavannepa et al., (2012).

The interaction of S X P was found to be significant at 120 DAE during 2014-15. All other interaction during 2013-14 and 2014-15 were found to be non significant.
Data on S X P interaction pertaining to 120 DAE is presented in Table 5. It was observed that $\mathrm{S}_{1} \mathrm{P}_{1}$ (monsoon sowing with plant density $60 \times 15 \mathrm{~cm}$ ) recorded significantly higher number of sympodial branches plant ${ }^{-1}$ at 120 DAE during 2014-15 season over rest of the treatments.

\section{Yield attributing characters}

\section{Number of picked bolls}

Weather variability significantly influenced the number of total picked bolls plant ${ }^{-1}$ (Table 6). Monsoon sowing $\left(S_{1}\right)$ recorded significantly higher boll numbers than the late sown $\left(\mathrm{S}_{2}\right)$ crop. Monsoon sown crop had $21.7 \%$ and $23.6 \%$ more bolls than late sown crop during 2013-14 and 2014-15 seasons, respectively. This could be due to fact that early planted crop initiated better reproductive growth and produced more sympodia and resultantly more squares that allowed the early planted crop to set more bolls utilizing the more favourable optimal environmental conditions. Hebber et al., (2010) and Adare et al., (2016) observed similar results.

The number of picked bolls plant ${ }^{-1}$ were significantly highest in plant density of $60 \mathrm{X}$ $15 \mathrm{~cm}\left(1.11,111\right.$ plants ha $\left.{ }^{-1}, \mathrm{P}_{1}\right)$. The number of picked bolls in plant density of $60 \times 10 \mathrm{~cm}$ $\left(1,66,666\right.$ plants $\left.\mathrm{ha}^{-1}, \mathrm{P}_{2}\right)$ was $16.7 \%$ less than $\mathrm{P}_{1}$ which was statistically equal with the plant density of $45 \mathrm{X} 10 \mathrm{~cm}\left(2.22,222\right.$ plants $\mathrm{ha}^{-1}$, $\mathrm{P}_{3}$ ) with $22.4 \%$ less bolls than $\mathrm{P}_{1}$ and $6.8 \%$ less than $\mathrm{P}_{2}$ during 2013-14. Similar trend prevailed during 2014-15 but $\mathrm{P}_{2}$ too proved significantly more over $\mathrm{P}_{3}$. The reduction in number of bolls in $\mathrm{P}_{2}$ and $\mathrm{P}_{3}$ were 17.6 and $27.9 \%$, respectively. Higher plant population under high planting density causes competition and fewer shares of limited resources to individual plants. Moreover, lower the plant population $\mathrm{ha}^{-1}$ may increase 
light penetration to allow more resources for fruit development lower in the canopy which may increase retention and hence number of bolls. Hake (1991) found that in dense stands fruiting branches are $25 \%$ shorter with more fruiting up the plants and slow development of new nodes. Resultantly plants produced fewer fruiting bodies and mature fruit plant ${ }^{-1}$. Under normal planting density overall favourable plant growth and development reflected in better source-sink relationship, which in turn enhanced the yield attributes. These findings are also in conformity with Reddy et al., (2009) and Naim et al., (2013).

Numbers of picked bolls plant ${ }^{-1}$ were significantly influenced by different fertilizer regimes. Fertilizer regime of 120:60:60 NPK $\mathrm{kg} \mathrm{ha}^{-1}$ recorded significantly higher number of picked bolls than 60:30:30 NPK kg ha ${ }^{-1}$ and on par with the fertilizer regimes of 90:45:45 NPK kg ha ${ }^{-1}$. Number of bolls increased by 9.3\% and $14.7 \%$ in $\mathrm{F}_{2}$ and $\mathrm{F}_{3}$ when compared with $\mathrm{F}_{1}$ during 2013-14. In 2014-15 also the highest number of picked bolls plant ${ }^{-1}$ was observed in 120:60:60 NPK kg ha-1 and least number of bolls was recorded in fertilizer regime of 60:30:30 NPK kg ha ${ }^{-1}$.The increase in number of picked bolls was $10.1 \%$ and $18.5 \%$ in $\mathrm{F}_{2}$ and $\mathrm{F}_{3}$ fertilizer regimes. The increase in number of picked bolls plant ${ }^{-1}$ with increase in fertilizer level was due to improvement in the growth attributes viz. plant height, number of monopodia and sympodia, leaf area and dry matter accumulation plant ${ }^{-1}$. Also the boll retention was more due to the availability of the nutrients to the crop during growth. Similar findings were also reported by Aruna and Reddy (2009) and Nehra and Yadav (2012).

Interaction effects were not significant during 2013-14 but during 2014-15, only S X P interaction was found significant. Interaction of weather variability with the plant density ( $S$ $X \quad P)$ significantly influenced number of picked bolls plant ${ }^{-1}$ during 2014-15 (Table 7). Treatment combination of $\mathrm{S}_{1} \mathrm{P}_{1}$ (monsoon sowing with plant density of $60 \times 15 \mathrm{~cm}$, $1,11,111$ plants $\mathrm{ha}^{-1}$ ) recorded significantly higher number of picked bolls plant ${ }^{-1}$ as compared to other treatment combinations.

\section{Boll weight}

Monsoon sowing was significantly higher in boll weight than late sowing during both the year of experimentation (Table 6). Reduction in the boll mass were $2.8 \%$ and $4.6 \%$ during 2013-14 and 2014-15, respectively. Hallikeri et al., (2009) revealed that early planted cotton produced bigger boll size due to higher accumulation of photosynthates and more time was available for boll development and maturity. Because of delayed sowing crop duration and total number of days required for maturity is reduced resulting in production of smaller size bolls. Similar results were observed by Dong et al., (2006), Hebber et al., (2010) and Ali et al., (2015).

Boll weight was significantly influenced due to different population density during 2014-15 but during 2013-14, differences in boll weight (g) did not reach to the level of significance due to different plant densities. The reduction in boll mass was 2.0 and $3.6 \%$; and 3.3 and $7.0 \%$ with the plant density increase in population density from $1,66,666$ plants $\mathrm{ha}^{-1}$ to 2,22,222 plants ha $^{-1}$ respectively during 201314 and 2014-15. Reduction in boll mass with higher plant density was lower during 2013-14 due to the sufficient rainfall received at boll development phenophase (242 to $232 \mathrm{~mm}$ ) and consequent low competition for resource like soil moisture (phenophases wise rainfall data not presented). During 2014-15 lower amount of rainfall coupled with early withdrawal of monsoon rains coincided with boll development which adversely affected the boll growth due to competition for soil moisture being particularly higher in higher 
plant density than lower plant density due to which boll mass was higher in lower plant density. According to Rose Roche et al., (2003) under ultra narrow row system in cotton less light is available to leaves lower in the canopy that are important to supporting boll growth. This may also be one of the reasons why boll size is smaller despite there being fewer bolls plant ${ }^{-1}$. Hakoomat Ali et al.,(2011) and Ramzan Ali et al., (2013) reported that boll weight $(\mathrm{g})$ decreased with increase in plant density. In contradiction Molin and Hugie (2010) observed that boll weight was not influenced by plant population.

Differences in boll weight did not reach to the level of significance due to varying fertilizer regime. Hebber et al., (2002) revealed that a non significant relation between fertilizer level and boll weight could be due to the prevailing weather and soil moisture conditions that might have constrained the utilization of nutrients from the soil by plants. Similar results were reported by Ram and Giri (2006) and Sharma (2004). None of the interaction was found to be significant.

\section{Seed cotton weight plant $^{-1}$}

Relevant data on seed cotton weight plant $^{-1}(\mathrm{~g})$ as influenced by different treatments are given in the Table 6. Differences in seed cotton weight plant $^{-1}(\mathrm{~g})$ under monsoon and late sowings were observed to be significant during both the years. Monsoon sowing recorded significantly higher seed cotton weight plant ${ }^{-1}$ (12.46 and $9.91 \mathrm{~g}$ ) as compared to late sowing (10.84 and $8.30 \mathrm{~g}$ ) during 201314 and 2014-15, respectively. Earliest sowing had more favourable and optimum environmental condition that allowed the plant to gain more in terms of reproductive growth which reflected in more seed cotton weight plant $^{-1}$. Better expression of yield components with early sowing was in conformity with the findings of Hallikari et al., (2009), Damahe et al., (2018) and Kumar et al., (2014).

Among different population densities, seed cotton weight plant $^{-1}$ was maximum with plant density of $60 \times 15 \mathrm{~cm}\left(1,11,111\right.$ plants $\mathrm{ha}^{-1}$, $\mathrm{P}_{1}$ ) during both years of experimentation. Plant density of $60 \times 10 \mathrm{~cm}(1,66,666$ plants $\mathrm{ha}^{-1}, \mathrm{P}_{2}$ ) also recorded numerically higher seed cotton weight plant ${ }^{-1}$ than plant density of 45 X $10 \mathrm{~cm}\left(2,22,222\right.$ plants $\left.\mathrm{ha}^{-1}, \mathrm{P}_{3}\right)$ but statistically both were at par. Optimum plant population while optimizing resource use produced more boll number plant ${ }^{-1}$ and boll weight that reflected in higher seed cotton weight plant ${ }^{-1}$. Under high density population probably due to reduced availability of resources to individual plant resultantly fewer boll number and smaller boll weight reflected in reduced seed cotton weight plant $^{-1}$. The aforesaid results are supported by the findings of Hiwale et al., (2016). Seed cotton weight plant $^{-1}$ was significantly influenced due to fertilizer regimes. Fertilizer regime of 120:60:60 NPK kg ha ${ }^{-1}\left(\mathrm{~F}_{3}\right)$ was significantly higher than 60:30:30 NPK kg ha ${ }^{-1}\left(\mathrm{~F}_{1}\right)$ and on par with the 90:45:45 NPK kg ha-1 $\left(\mathrm{F}_{2}\right)$ during 2013-14. During 2014-15, $\mathrm{F}_{3}$ fertilizer regime (120:60:60 NPK kg ha ${ }^{-1}$ ) was significantly superior over both $\mathrm{F}_{2}\left(90: 45: 45 \mathrm{NPK} \mathrm{kg} \mathrm{ha}{ }^{-1}\right.$ ) and $F_{1}\left(60: 30: 30\right.$ NPK $\left.\mathrm{kg} \mathrm{ha}^{-1}\right)$. Increase in seed cotton yield plant $^{-1}$ was attributed to increased number of picked bolls per plant and boll weight with 120:60:60 NPK $\mathrm{kg} \mathrm{ha}^{-1}$. Similar trend in seed cotton yield plant ${ }^{-1}$ with increase in fertilizer regimes was reported by Ambati Raju and Soniya Thakare (2012), and Katkar et al., (2005). As regards seed cotton yield plant $^{-1}$ none of the interaction effects were found to be statistically significant.

\section{Seed cotton yield}

Mean seed cotton yield was $1657 \mathrm{~kg}$ and 1215 $\mathrm{kg} \mathrm{ha}^{-1}$ during 2013-14 and 2014-15 seasons and $1436 \mathrm{~kg} \mathrm{ha}^{-1}$ in pooled analysis (Table 8). 
Comparatively higher seed cotton yield in 2013-14 might be due to extended crop duration.

Weather created through different sowing time significantly influenced the seed cotton yield. Significantly higher seed cotton yield (1846 and $1359 \mathrm{~kg} \mathrm{ha}^{-1}$ ) was obtained with monsoon sowing and it was significantly decreased in late sowing (1467 and $1071 \mathrm{~kg} \mathrm{ha}^{-1}$ ) during 2013-14 and 2014-15 respectively. In pooled data with similar statistical trend, seed cotton yield was observed 1602 and $1269 \mathrm{~kg} \mathrm{ha}^{-1}$ in monsoon and late sowing, respectively. Reduction in yield due to delay in sowing was to the extent of $20.5 \%, 21.2 \%$ and $20.8 \%$ respectively during 2013-14, 2014-15 and in pooled. In the present study, mean values were higher as regards growth and yield parameters under monsoon sowing. Reduction of yield in late sowing was also due to shortening of total crop duration which affected reproductive process of the crop adversely. Higher retention of bolls in early sown crop and shedding of floral structure in late sown crop might have also affected the seed cotton yield. By and large, decrease in yield under late sowing was due to significant decrease in growth attributes, number of bolls harvested plant ${ }^{-1}$, boll weight and seed cotton yield plant ${ }^{-1}$. This is in conformity with the findings of Hallikaeri et al., (2009), Kumar et al., (2014), Ban et al., (2015), Dalvi et al., (2015) and Pinky et al., (2016).

Population density of 2.22 lakh plants $\mathrm{ha}^{-1}$ (45 $\mathrm{X} 10 \mathrm{~cm}$ ) produced significantly highest seed cotton yield over population of 1.66 lakh plants $\mathrm{ha}^{-1}(60 \times 10 \mathrm{~cm})$ and 1.11 lakh plants $\mathrm{ha}^{-1}(60 \times 15 \mathrm{~cm})$. Least seed cotton yield was recorded in $60 \times 15 \mathrm{~cm}$ (1.11 lakh plants ha $\left.{ }^{-1}\right)$. Similar results were observed during both the years of experimentation and in pooled analysis. High density planting had helped to produce higher biomass at all the growth stages because of optimal light penetration and uptake of major nutrients which favored for increased photosynthetic efficiency. Higher plant density treatment $\mathrm{P}_{3}$ (2.22 lakh plants ha $\left.{ }^{1}\right)$ though had smaller individual boll mass (weight) and fewer bolls plants ${ }^{-1}$, however, the increased number of plants compensated for fewer boll number and smaller boll size and cumulatively yield output was higher under high population density. These results are in agreement with reports of Bhalerao et al., (2012), Paslawar et al., (2015), and Sankaranarayanan et al., (2018).

Seed cotton yield was significantly influenced by varying fertilizer regimes. Fertilizer regime of 120:60: $60 \mathrm{NPK} \mathrm{kg} \mathrm{ha}{ }^{-1}$ was significantly superior over 60:30:30 NPK kg ha ${ }^{-1}$ and on par with 90:45:45 NPK kg ha-1 during 2013-14. During 2014-15, fertilizer regime of 120:60:60 NPK $\mathrm{kg} \mathrm{ha}^{-1}$ recorded significantly higher seed cotton yield as compared to both lower fertilizer regimes (90:45:45 and 60:30:30 NPK $\left.\mathrm{kg} \mathrm{ha}^{-1}\right)$. Similar trend as of 2014-15 prevailed in pooled analysis also. The increase in seed cotton yield was to the extent of $10.7 \%$ and $17.1 \%$ during $2013-14$ and $14.4 \%$ and $24.6 \%$ in 2014 with increase in fertilizer regimes to 90:45:45 and 120:60: 60 NPK kg ha ${ }^{-1}$, respectively compared to the lowest fertilizer regime of 60:30:30 NPK kg ha' ${ }^{-1}$ In pooled data, corresponding increase in seed cotton yield was to the extent of 12.2 and $20.2 \%$ with increase in fertilizer regimes. Significant increase in seed cotton yield with increase in fertilizer regime was the result of associated increase in various growth and yield attributing characters viz. plant height, number of monopodia and sympodia branches, leaf area which produced more photosynthates and that had reflected in higher dry matter, number of bolls, boll weight, seed cotton yield plant ${ }^{-1}$ and ultimately higher seed cotton yield. The above results also corroborate the findings by Singh et al., (2014) and Hargilas and Saini (2018). 
Table.1 Influence of weather variability, plant density and fertilizer regime on plant height $(\mathrm{cm})$ of cotton

\begin{tabular}{|c|c|c|c|c|c|c|c|c|c|c|}
\hline & & & 2013-1 & & & & & 2014- & & \\
\hline & $\begin{array}{l}30 \\
\text { DAE }\end{array}$ & $\begin{array}{l}60 \\
\text { DAE }\end{array}$ & $\begin{array}{l}90 \\
\text { DAE }\end{array}$ & $\begin{array}{l}\text { 120D } \\
\mathrm{AE}\end{array}$ & $\begin{array}{c}\text { At } \\
\text { harvest }\end{array}$ & $\begin{array}{l}30 \\
\text { DAE }\end{array}$ & $\begin{array}{l}60 \\
\text { DAE }\end{array}$ & $\begin{array}{l}90 \\
\text { DAE }\end{array}$ & $\begin{array}{l}120 \\
\text { DAE }\end{array}$ & At harvest \\
\hline Main plot treatment & & & & & & & & & & \\
\hline A) Weather variability & & & & & & & & & & \\
\hline$S_{1}$ - Monsoon sowing & 24.50 & 54.02 & 63.74 & 66.52 & 69.05 & 18.13 & 32.08 & 43.06 & 45.99 & 47.59 \\
\hline$S_{2}$ - Late sowing & 16.83 & 33.33 & 49.50 & 55.04 & 58.67 & 15.55 & 30.41 & 38.95 & 40.47 & 42.18 \\
\hline $\mathrm{SE}(\mathrm{m}) \pm$ & 0.47 & 1.04 & 1.03 & 1.17 & 1.48 & 0.40 & 0.43 & 0.52 & 0.58 & 0.65 \\
\hline $\mathrm{CD}(\mathrm{P}=0.05)$ & 1.47 & 3.28 & 3.23 & 3.68 & 4.67 & 1.25 & 1.36 & 1.62 & 1.83 & 2.05 \\
\hline B) Plant density & & & & & & & & & & \\
\hline$P_{1}-60 \times 15 \mathrm{~cm}\left(1,11,111\right.$ plants $\left.\mathrm{ha}^{-1}\right)$ & 19.04 & 41.84 & 54.96 & 58.90 & 63.39 & 16.03 & 29.59 & 39.63 & 42.65 & 44.10 \\
\hline$P_{2^{-}} 60 \times 10 \mathrm{~cm}\left(1,66,666\right.$ plants $\left.\mathrm{ha}^{-1}\right)$ & 20.62 & 42.02 & 55.34 & 59.12 & 61.49 & 16.71 & 32.09 & 41.03 & 43.38 & 45.65 \\
\hline$P_{3^{-}} 45 X 10 \mathrm{~cm}\left(2,22,222\right.$ plants $\left.\mathrm{ha}^{-1}\right)$ & 22.33 & 47.17 & 59.57 & 64.31 & 66.70 & 17.77 & 32.07 & 42.35 & 43.67 & 44.89 \\
\hline $\mathrm{SE}(\mathbf{m}) \pm$ & 0.57 & 1.28 & 1.26 & 1.43 & 1.82 & 0.49 & 0.53 & 0.63 & 0.71 & 0.80 \\
\hline $\mathrm{CD}(\mathrm{P}=0.05)$ & 1.81 & 4.02 & 3.96 & 4.51 & NS & NS & 1.67 & 1.99 & NS & NS \\
\hline Sub plot treatment & & & & & & & & & & \\
\hline Fertilizer regime & & & & & & & & & & \\
\hline$F_{1}-$ RDF (60:30:30 NPK kg ha $\left.{ }^{-1}\right)$ & 19.45 & 40.41 & 53.11 & 56.86 & 60.54 & 15.76 & 29.17 & 38.47 & 40.86 & 42.96 \\
\hline $\mathrm{F}_{2}-150 \% \mathrm{RDF}\left(90: 45: 45 \mathrm{NPK} \mathrm{kg} \mathrm{ha}^{-1}\right)$ & 21.01 & 44.44 & 57.54 & 61.60 & 65.14 & 17.13 & 31.53 & 41.07 & 43.64 & 45.03 \\
\hline$F_{3}-200 \%$ RDF(120:60:60 NPK kg ha $\left.{ }^{-1}\right)$ & 21.53 & 46.18 & 59.21 & 63.88 & 65.90 & 17.63 & 33.04 & 43.48 & 45.20 & 46.65 \\
\hline $\mathrm{SE}(\mathrm{m}) \pm$ & 0.39 & 1.05 & 1.26 & 1.33 & 1.32 & 0.27 & 0.51 & 0.65 & 0.58 & 0.56 \\
\hline $\mathrm{CD}(\mathrm{P}=\mathbf{0 . 0 5})$ & 1.15 & 3.05 & 3.67 & 3.88 & 3.86 & 0.79 & 1.50 & 1.89 & 1.70 & 1.64 \\
\hline Interaction & & & & & & & & & & \\
\hline $\mathbf{S X} \mathbf{P}$ & & & & & & & & & & \\
\hline $\mathrm{SE}(\mathrm{m}) \pm$ & 0.81 & 1.80 & 1.78 & 2.02 & 2.57 & 0.69 & 0.75 & 0.89 & 1.01 & 1.13 \\
\hline $\mathrm{CD}(\mathrm{P}=0.05)$ & 2.55 & NS & NS & NS & NS & NS & NS & NS & NS & NS \\
\hline SX F & & & & & & & & & & \\
\hline
\end{tabular}




\begin{tabular}{|c|c|c|c|c|c|c|c|c|c|c|}
\hline $\mathrm{SE}(\mathrm{m}) \pm$ & 0.56 & 1.48 & 1.78 & 1.88 & 1.87 & 0.38 & 0.73 & 0.92 & 0.83 & 0.80 \\
\hline $\mathrm{CD}(\mathrm{P}=0.05)$ & NS & NS & NS & NS & NS & NS & NS & NS & NS & NS \\
\hline \multicolumn{11}{|l|}{$\mathbf{P X} \mathbf{F}$} \\
\hline $\mathrm{SE}(\mathrm{m}) \pm$ & 0.68 & 1.81 & 2.18 & 2.30 & 2.29 & 0.47 & 0.89 & 1.12 & 1.01 & 0.98 \\
\hline $\mathrm{CD}(\mathrm{P}=\mathbf{0 . 0 5})$ & 1.99 & NS & NS & NS & NS & NS & NS & NS & NS & NS \\
\hline \multicolumn{11}{|l|}{ SX P X F } \\
\hline $\mathrm{SE}(\mathrm{m}) \pm$ & 0.97 & 2.56 & 3.08 & 3.26 & 3.24 & 0.66 & 1.26 & 1.59 & 1.43 & 1.38 \\
\hline $\mathrm{CD}(\mathrm{P}=0.05)$ & NS & NS & NS & NS & NS & NS & NS & NS & NS & NS \\
\hline GM & 20.66 & 43.68 & 56.62 & 60.78 & 63.86 & 16.84 & 31.25 & 41.01 & 43.23 & 44.88 \\
\hline
\end{tabular}

Table.2 Plant height as influenced by S X P interaction at 30 DAE during 2013-14

\begin{tabular}{|l|c|c|c|}
\hline S/P & $\mathbf{P}_{\mathbf{1}}$ & $\mathbf{P}_{\mathbf{2}}$ & $\mathbf{P}_{\mathbf{3}}$ \\
\hline $\mathbf{S}_{\mathbf{1}}$ & 21.73 & 24.02 & 27.33 \\
\hline $\mathbf{S}_{\mathbf{2}}$ & 16.36 & 17.21 & 16.93 \\
\hline S.E. $(\mathbf{m}) \pm$ & & 0.81 & \\
\hline CD $(\mathbf{P}=\mathbf{0 . 0 5})$ & & 2.56 & \\
\hline
\end{tabular}

Table.3 Plant height as influenced by P X F interaction at 30 DAE during 2013-14

\begin{tabular}{|l|c|c|c|}
\hline $\mathbf{P} / \mathbf{F}$ & $\mathbf{F}_{\mathbf{1}}$ & $\mathbf{F}_{\mathbf{2}}$ & $\mathbf{F}_{\mathbf{3}}$ \\
\hline $\mathbf{P}_{\mathbf{1}}$ & 17.53 & 19.90 & 19.70 \\
\hline $\mathbf{P}_{\mathbf{2}}$ & 20.15 & 21.47 & 20.23 \\
\hline $\mathbf{P}_{\mathbf{3}}$ & 20.67 & 21.67 & 24.67 \\
\hline S.E. $(\mathbf{m}) \pm$ & & 0.68 & \\
\hline CD $\mathbf{( P = 0 . 0 5 )}$ & & 1.99 & \\
\hline
\end{tabular}


Table.4 Influence of weather variability, plant density and fertilizer regime on sympodial branches plant ${ }^{-1}$

\begin{tabular}{|c|c|c|c|c|c|c|c|c|}
\hline \multirow[t]{2}{*}{ Treatment } & \multicolumn{4}{|c|}{ 2013-14 } & \multicolumn{4}{|c|}{ 2014-15 } \\
\hline & $\begin{array}{c}\text { 60 } \\
\text { DAE }\end{array}$ & $\begin{array}{c}90 \\
\text { DAE }\end{array}$ & $\begin{array}{c}120 \\
\text { DAE }\end{array}$ & $\begin{array}{c}\text { At } \\
\text { harvest }\end{array}$ & $\begin{array}{c}60 \\
\text { DAE }\end{array}$ & $\begin{array}{c}90 \\
\text { DAE }\end{array}$ & $\begin{array}{c}\text { 120 } \\
\text { DAE }\end{array}$ & $\begin{array}{c}\text { At } \\
\text { harvest }\end{array}$ \\
\hline \multicolumn{9}{|l|}{ Main plot treatment } \\
\hline \multicolumn{9}{|l|}{ A) Weather variability } \\
\hline$S_{1}-$ Monsoon sowing & 7.69 & 8.63 & 9.28 & 9.39 & 5.36 & 5.99 & 6.61 & 7.01 \\
\hline$S_{2^{-}}$Late sowing & 5.50 & 6.36 & 7.38 & 7.82 & 4.64 & 5.62 & 5.87 & 5.96 \\
\hline $\mathbf{S E}(\mathbf{m}) \pm$ & 0.13 & 0.14 & 0.22 & 0.19 & 0.08 & 0.10 & 0.10 & 0.14 \\
\hline $\mathrm{CD}(\mathrm{P}=\mathbf{0 . 0 5})$ & 0.41 & 0.45 & 0.68 & 0.61 & 0.27 & 0.31 & 0.33 & 0.44 \\
\hline \multicolumn{9}{|l|}{ B) Plant density } \\
\hline$P_{1^{-}} 60 \times 15 \mathrm{~cm}\left(1,11,111\right.$ plants ha $\left.{ }^{-1}\right)$ & 7.03 & 7.90 & 8.88 & 9.13 & 5.22 & 6.06 & 6.60 & 6.73 \\
\hline$P_{2^{-}} 60 \times 10 \mathrm{~cm}\left(1,66,666\right.$ plants $\left.\mathrm{ha}^{-1}\right)$ & 6.46 & 7.41 & 8.40 & 8.73 & 5.05 & 5.90 & 6.20 & 6.65 \\
\hline$P_{3^{-}}-45 X 10 \mathrm{~cm}\left(2,22,222\right.$ plants $\left.\mathrm{ha}^{-1}\right)$ & 6.29 & 7.17 & 7.71 & 7.95 & 4.74 & 5.46 & 5.92 & 6.08 \\
\hline $\mathrm{SE}(\mathrm{m}) \pm$ & 0.16 & 0.17 & 0.26 & 0.24 & 0.10 & 0.12 & 0.13 & 0.17 \\
\hline $\mathrm{CD}(\mathrm{P}=0.05)$ & 0.51 & 0.55 & 0.83 & 0.75 & 0.33 & 0.38 & 0.40 & 0.54 \\
\hline \multicolumn{9}{|l|}{ Sub plot treatment } \\
\hline \multicolumn{9}{|l|}{ Fertilizer regime } \\
\hline$F_{1}-\operatorname{RDF}\left(60: 30: 30\right.$ NPK kg ha $\left.{ }^{-1}\right)$ & 6.02 & 6.78 & 7.89 & 8.13 & 4.42 & 5.44 & 5.76 & 6.03 \\
\hline$F_{2}-150 \%$ RDF (90:45:45 NPK kg ha $\left.{ }^{-1}\right)$ & 6.80 & 7.70 & 8.42 & 8.68 & 4.97 & 5.83 & 6.26 & 6.52 \\
\hline$F_{3}-200 \%$ RDF (120:60:60 NPK kg ha $\left.{ }^{-1}\right)$ & 6.96 & 8.00 & 8.68 & 9.00 & 5.62 & 6.13 & 6.71 & 6.92 \\
\hline $\mathrm{SE}(\mathrm{m}) \pm$ & 0.12 & 0.22 & 0.21 & 0.20 & 0.16 & 0.11 & 0.12 & 0.19 \\
\hline $\mathrm{CD}(\mathrm{P}=0.05)$ & 0.36 & 0.65 & 0.60 & 0.59 & 0.45 & 0.32 & 0.36 & 0.54 \\
\hline \multicolumn{9}{|l|}{ Interaction } \\
\hline \multicolumn{9}{|l|}{ S X P } \\
\hline $\mathrm{SE}(\mathrm{m}) \pm$ & 0.23 & 0.25 & 0.37 & 0.33 & 0.15 & 0.17 & 0.18 & 0.24 \\
\hline $\mathrm{CD}(\mathrm{P}=0.05)$ & NS & NS & NS & NS & NS & NS & 0.57 & NS \\
\hline \multicolumn{9}{|l|}{ SX F } \\
\hline $\mathrm{SE}(\mathrm{m}) \pm$ & 0.17 & 0.31 & 0.29 & 0.29 & 0.22 & 0.16 & 0.17 & 0.26 \\
\hline $\mathrm{CD}(\mathrm{P}=0.05)$ & NS & NS & NS & NS & NS & NS & NS & NS \\
\hline \multicolumn{9}{|l|}{ P X F } \\
\hline $\mathrm{SE}(\mathrm{m}) \pm$ & 0.21 & 0.38 & 0.36 & 0.35 & 0.27 & 0.19 & 0.21 & 0.32 \\
\hline CD $(P=0.05)$ & NS & NS & NS & NS & NS & NS & NS & NS \\
\hline \multicolumn{9}{|l|}{ SX P X F } \\
\hline $\mathrm{SE}(\mathrm{m}) \pm$ & 0.30 & 0.54 & 0.50 & 0.50 & 0.38 & 0.27 & 0.30 & 0.46 \\
\hline $\mathrm{CD}(\mathrm{P}=0.05)$ & NS & NS & NS & NS & NS & NS & NS & NS \\
\hline GM & 6.59 & 7.49 & 8.33 & 8.60 & 5.00 & 5.80 & 6.24 & 6.49 \\
\hline
\end{tabular}

Table.5 Number of sympodial branches plant-1 as influenced by S X P interaction at 120 DAE during 2014-15

\begin{tabular}{|l|c|c|c|}
\hline $\mathbf{S} / \mathbf{P}$ & $\mathbf{P}_{\mathbf{1}}$ & $\mathbf{P}_{\mathbf{2}}$ & $\mathbf{P}_{\mathbf{3}}$ \\
\hline $\mathbf{S}_{\mathbf{1}}$ & 7.24 & 6.56 & 6.02 \\
\hline $\mathbf{S}_{\mathbf{2}}$ & 5.96 & 5.84 & 5.82 \\
\hline S.E. $(\mathbf{m}) \pm$ & & 0.18 & \\
\hline CD $(\mathbf{P}=\mathbf{0 . 0 5})$ & & 0.57 & \\
\hline
\end{tabular}


Table.6 Influence of weather variability, plant density and fertilizer regime on yield attributing characters and seed cotton weight plant-1 (g)

\begin{tabular}{|c|c|c|c|c|c|c|}
\hline \multirow[t]{2}{*}{ Treatment } & \multicolumn{3}{|c|}{ 2013-14 } & \multicolumn{3}{|c|}{ 2014-15 } \\
\hline & $\begin{array}{l}\text { No. of } \\
\text { picked bolls } \\
\text { plant }^{-1}\end{array}$ & $\begin{array}{c}\text { Boll } \\
\text { s weight (g) }\end{array}$ & $\begin{array}{l}\text { Seed } \\
\text { cotton } \\
\text { weight } \\
\text { plant }^{-1}(g)\end{array}$ & $\begin{array}{l}\text { No. of } \\
\text { picked bolls } \\
\text { plant }^{-1}\end{array}$ & $\begin{array}{c}\text { Boll } \\
\text { weight } \\
\text { (g) }\end{array}$ & $\begin{array}{l}\text { Seed cotton } \\
\text { weight } \\
\text { plant }^{-1} \\
\text { (g) }\end{array}$ \\
\hline \multicolumn{7}{|l|}{ Main plot treatment } \\
\hline \multicolumn{7}{|l|}{ A) Weather variability } \\
\hline$S_{1}-$ Monsoon sowing & 5.88 & 2.47 & 12.46 & 4.92 & 2.40 & 9.91 \\
\hline$S_{2}$ - Late sowing & 4.83 & 2.40 & 10.84 & 3.98 & 2.29 & 8.30 \\
\hline $\mathrm{SE}(\mathrm{m}) \pm$ & 0.12 & 0.02 & 0.34 & 0.07 & 0.03 & 0.25 \\
\hline $\mathrm{CD}(\mathrm{P}=\mathbf{0 . 0 5})$ & 0.38 & 0.06 & 1.06 & 0.21 & 0.08 & 0.79 \\
\hline \multicolumn{7}{|l|}{ B) Plant density } \\
\hline$P_{1^{-}} 60 \times 15 \mathrm{~cm}\left(1,11,111\right.$ plants $\left.\mathrm{ha}^{-1}\right)$ & 6.16 & 2.48 & 14.14 & 5.24 & 2.43 & 10.75 \\
\hline$P_{2^{-}} 60 \times 10 \mathrm{~cm}\left(1,66,666\right.$ plants $\left.\mathrm{ha}^{-1}\right)$ & 5.13 & 2.43 & 11.26 & 4.32 & 2.35 & 8.62 \\
\hline$P_{3^{-}} 45 \times 10 \mathrm{~cm}\left(2,22,222\right.$ plants $\left.\mathrm{ha}^{-1}\right)$ & 4.78 & 2.39 & 9.55 & 3.78 & 2.26 & 7.95 \\
\hline $\mathrm{SE}(\mathrm{m}) \pm$ & 0.22 & 0.09 & 0.41 & 0.08 & 0.03 & 0.31 \\
\hline $\mathrm{CD}(\mathrm{P}=0.05)$ & 0.70 & NS & 1.30 & 0.26 & 0.10 & 0.97 \\
\hline \multicolumn{7}{|l|}{ Sub plot treatment } \\
\hline \multicolumn{7}{|l|}{ Fertilizer regime } \\
\hline$F_{1}-\operatorname{RDF}\left(60: 30: 30\right.$ NPK $\left.\mathrm{kg} \mathrm{ha}^{-1}\right)$ & 4.96 & 2.40 & 10.37 & 4.06 & 2.30 & 8.34 \\
\hline$F_{2}-150 \%$ RDF (90:45:45 NPK kg ha $\left.{ }^{-1}\right)$ & 5.42 & 2.43 & 11.93 & 4.47 & 2.35 & 9.14 \\
\hline$F_{3}-200 \% R D F\left(120: 60: 60 \mathrm{NPK} \mathrm{kg} \mathrm{ha}^{-1}\right)$ & 5.69 & 2.46 & 12.65 & 4.81 & 2.38 & 9.84 \\
\hline $\mathrm{SE}(\mathrm{m}) \pm$ & 0.11 & 0.02 & 0.34 & 0.10 & 0.03 & 0.19 \\
\hline $\mathrm{CD}(\mathrm{P}=\mathbf{0 . 0 5})$ & 0.32 & NS & 1.00 & 0.28 & NS & 0.56 \\
\hline \multicolumn{7}{|l|}{ Interaction } \\
\hline \multicolumn{7}{|l|}{$\mathbf{S X P}$} \\
\hline $\mathrm{SE}(\mathrm{m}) \pm$ & 0.21 & 0.03 & 0.58 & 0.12 & 0.04 & 0.43 \\
\hline $\mathrm{CD}(\mathrm{P}=\mathbf{0 . 0 5})$ & NS & NS & NS & 0.37 & NS & NS \\
\hline \multicolumn{7}{|l|}{ SX F } \\
\hline $\mathrm{SE}(\mathrm{m}) \pm$ & 0.15 & 0.03 & 0.48 & 0.14 & 0.04 & 0.27 \\
\hline $\mathrm{CD}(\mathrm{P}=0.05)$ & NS & NS & NS & NS & NS & NS \\
\hline \multicolumn{7}{|l|}{ P X F } \\
\hline $\mathrm{SE}(\mathrm{m}) \pm$ & 0.19 & 0.04 & 0.59 & 0.17 & 0.05 & 0.33 \\
\hline $\mathrm{CD}(\mathrm{P}=0.05)$ & NS & NS & NS & NS & NS & NS \\
\hline \multicolumn{7}{|l|}{ SX P X F } \\
\hline SE(m)士 & 0.27 & 0.06 & 0.84 & 0.24 & 0.07 & 0.47 \\
\hline $\mathrm{CD}(\mathrm{P}=0.05)$ & NS & NS & NS & NS & NS & NS \\
\hline GM & 5.36 & 2.43 & 11.65 & 4.45 & 2.35 & 9.11 \\
\hline
\end{tabular}

Table.7 Number of picked bolls plant-1 as influenced by S X P interaction during 2014-15

\begin{tabular}{|l|c|c|c|}
\hline $\mathbf{S} / \mathbf{P}$ & $\mathbf{P}_{\mathbf{1}}$ & $\mathbf{P}_{\mathbf{2}}$ & $\mathbf{P}_{\mathbf{3}}$ \\
\hline $\mathbf{S}_{\mathbf{1}}$ & 5.80 & 4.91 & 4.04 \\
\hline $\mathbf{S}_{\mathbf{2}}$ & 4.67 & 3.73 & 3.53 \\
\hline $\mathbf{S . E}(\mathbf{m}) \pm$ & & 0.12 & \\
\hline $\mathbf{C D}(\mathbf{P}=\mathbf{0 . 0 5})$ & & 0.37 & \\
\hline
\end{tabular}


Table.8 Seed cotton yield and stalk yield as influenced by the weather variability, plant density and fertilizer regime

\begin{tabular}{|c|c|c|c|c|c|c|}
\hline \multirow[t]{2}{*}{ Treatment } & \multicolumn{3}{|c|}{ Seed cotton yield $\left(\mathrm{kg} \mathrm{ha}^{-1}\right)$} & \multicolumn{3}{|c|}{ Stalk yield $\left(\mathrm{kg} \mathrm{ha}^{-1}\right)$} \\
\hline & 2013-14 & 2014-15 & Pooled & 2013-14 & 2014-15 & Pooled \\
\hline \multicolumn{7}{|l|}{ Main plot treatment } \\
\hline \multicolumn{7}{|l|}{ A) Weather variability } \\
\hline$S_{1}-$ Monsoon sowing & 1846 & 1359 & 1602 & 4096 & 2933 & 3514 \\
\hline$S_{2}$ - Late sowing & 1467 & 1071 & 1269 & 3445 & 2390 & 2917 \\
\hline $\mathbf{S E}(\mathbf{m}) \pm$ & 32 & 19 & 22 & 106 & 44 & 66 \\
\hline $\mathrm{CD}(\mathrm{P}=\mathbf{0 . 0 5})$ & 101 & 61 & 68 & 335 & 139 & 207 \\
\hline \multicolumn{7}{|l|}{ B) Plant density } \\
\hline$P_{1^{-}} 60 \times 15 \mathrm{~cm}\left(1.11\right.$ lakh plants ha $\left.{ }^{-1}\right)$ & 1328 & 1041 & 1185 & 2818 & 1948 & 2383 \\
\hline$P_{2^{-}} 60 \times 10 \mathrm{~cm}\left(1.66\right.$ lakh plants $\left.\mathrm{ha}^{-1}\right)$ & 1682 & 1195 & 1439 & 3819 & 2847 & 3333 \\
\hline$P_{3^{-}} 45 \times 10 \mathrm{~cm}\left(2.22\right.$ lakh plants ha $\left.{ }^{-1}\right)$ & 1959 & 1409 & 1684 & 4674 & 3190 & 3932 \\
\hline $\mathrm{SE}(\mathbf{m}) \pm$ & 39 & 24 & 26 & 130 & 54 & 81 \\
\hline $\mathrm{CD}(\mathrm{P}=0.05)$ & 124 & 75 & 83 & 410 & 170 & 254 \\
\hline \multicolumn{7}{|l|}{ Sub plot treatment } \\
\hline \multicolumn{7}{|l|}{ Fertilizer regime } \\
\hline$F_{1}-\operatorname{RDF}\left(60: 30: 30\right.$ NPK kg ha $\left.{ }^{-1}\right)$ & 1516 & 1075 & 1296 & 3452 & 2362 & 2907 \\
\hline$F_{2}-150 \% \operatorname{RDF}\left(90: 45: 45 \mathrm{NPK}_{\mathrm{kg} \mathrm{ha}}{ }^{-1}\right)$ & 1678 & 1230 & 1454 & 3789 & 2668 & 3229 \\
\hline$F_{3}-200 \% \operatorname{RDF}\left(120: 60: 60 \mathrm{NPK} \mathrm{kg} \mathrm{ha}^{-1}\right)$ & 1775 & 1340 & 1558 & 4070 & 2955 & 3512 \\
\hline $\mathrm{SE}(\mathrm{m}) \pm$ & 38 & 17 & 21 & 79 & 59 & 54 \\
\hline $\mathrm{CD}(\mathbf{P}=\mathbf{0 . 0 5})$ & 112 & 49 & 61 & 231 & 172 & 159 \\
\hline \multicolumn{7}{|l|}{ Interaction } \\
\hline \multicolumn{7}{|l|}{ S X P } \\
\hline $\mathrm{SE}(\mathrm{m}) \pm$ & 56 & 34 & 37 & 184 & 76 & 114 \\
\hline $\mathrm{CD}(\mathrm{P}=0.05)$ & NS & 106 & NS & NS & 240 & NS \\
\hline \multicolumn{7}{|l|}{ SX F } \\
\hline SE(m) \pm & 54 & 24 & 29 & 112 & 84 & 77 \\
\hline $\mathrm{CD}(\mathbf{P}=0.05)$ & NS & NS & NS & NS & NS & NS \\
\hline \multicolumn{7}{|l|}{ PX F } \\
\hline $\mathrm{SE}(\mathrm{m}) \pm$ & 66 & 29 & 36 & 137 & 102 & 94 \\
\hline $\mathrm{CD}(\mathrm{P}=0.05)$ & NS & NS & NS & NS & NS & NS \\
\hline \multicolumn{7}{|l|}{ SX P X F } \\
\hline SE(m) \pm & 94 & 41 & 51 & 194 & 145 & 133 \\
\hline $\mathrm{CD}(\mathrm{P}=0.05)$ & NS & NS & NS & NS & NS & NS \\
\hline GM & 1657 & 1215 & 1436 & 3770 & 2662 & 3216 \\
\hline
\end{tabular}

Table.9 Seed cotton and stalk yield $\left(\mathrm{kg} \mathrm{ha}^{-1}\right)$ as influenced by S X P interaction during 2014-15

\begin{tabular}{|l|c|c|c|c|c|c|}
\hline & \multicolumn{3}{|c|}{ Seed cotton yield } & \multicolumn{3}{c|}{ Cotton stalk yield } \\
\hline $\mathbf{S} / \mathbf{P}$ & $\mathbf{P}_{\mathbf{1}}$ & $\mathbf{P}_{\mathbf{2}}$ & $\mathbf{P}_{\mathbf{3}}$ & $\mathbf{P}_{\mathbf{1}}$ & $\mathbf{P}_{\mathbf{2}}$ & $\mathbf{P}_{\mathbf{3}}$ \\
\hline $\mathbf{S}_{\mathbf{1}}$ & 1139 & 1390 & 1547 & 2208 & 3234 & 3357 \\
\hline $\mathbf{S}_{\mathbf{2}}$ & 943 & 1001 & 1270 & 1687 & 2461 & 3023 \\
\hline $\mathbf{S . E}(\mathbf{m}) \pm$ & & 34 & & & 76 & \\
\hline $\mathbf{C D}(\mathbf{P}=\mathbf{0 . 0 5})$ & & 106 & & 240 \\
\hline
\end{tabular}


Interaction effect of weather variability and plant density (S X P) was found significant during 2014-15 (Table 9). Remaining interaction effects were non significant during 2013-14, 2014-15 and in pooled analysis. The treatment combination of $\mathrm{S}_{1} \mathrm{P}_{3}$ (monsoon sowing with plant density of $45 \times 10 \mathrm{~cm}, 2.22$ lakh plants ha ${ }^{-1}$ ) recorded significantly highest seed cotton yield (1547 kg ha $\left.{ }^{-1}\right)$.

\section{Stalk yield}

Data on cotton stalk yield as influenced by different treatments are presented in Table 8. Cotton stalk yield was significantly decreased with the late sowing. Significantly higher stalk yield of cotton was recorded in monsoon sowing (4096 and $2933 \mathrm{~kg} \mathrm{ha}^{-1}$ ) as compared to late sowing (3445 and $2390 \mathrm{~kg} \mathrm{ha}^{-1}$ ). Similar trend of the result was observed during 2013-14, 2014-15 and in pooled data (3514 and $2917 \mathrm{~kg} \mathrm{ha}^{-1}$ ). Hallikeri et al., (2009) and Pinky Patel et al., (2016) also observed that early sown crop recorded higher stalk yield over the subsequent late sowing. High population density of $45 \times 10 \mathrm{~cm}(2.22$ lakh plants $\mathrm{ha}^{-1}$ ) recorded significantly highest stalk yield $\left(4674,3190\right.$ and $3932 \mathrm{~kg} \mathrm{ha}^{-1}$ ) followed by $60 \times 10 \mathrm{~cm}(3819,2847$ and $\left.3333 \mathrm{~kg} \mathrm{ha}^{-1}\right)$ and $60 \times 15 \mathrm{~cm}(2818,1948$ and $2383 \mathrm{~kg} \mathrm{ha}^{-1}$ ) during 2013-14, 2014-15 and in pooled result. Similar results were also observed by Hake (2017) and Kharagkharate et al., (2017). The concurrent increase in fertilizer regimes resulted in significant increase in stalk yield over its preceding lower levels during both the years and in pooled data. Significantly highest stalk yield was observed in 120:60:60 NPK kg ha followed by 90:45:45 NPK kg ha-1 and least stalk yield in 60:30:30 NPK kg ha-1. Application of higher quantity of fertilizer, increased vegetative attributes and accumulation of dry matter plant ${ }^{-1}$ was higher. These results are in conformity with findings of Hiwale et al., (2016).
Weather variability and plant density interaction (S X P) was found significant in respect of stalk yield during 2014-15 (Table 9). The interaction of $\mathrm{S}_{1} \mathrm{P}_{3}$ i.e. monsoon sowing with plant density of $45 \times 10 \mathrm{~cm}(2.22$ lakh plants $\mathrm{ha}^{-1}$ ) recorded significantly higher stalk yield (3357 $\mathrm{kg} \mathrm{ha}^{-1}$ ) and it was on par with treatment combination of $\mathrm{S}_{1} \mathrm{P}_{2}$ (monsoon sowing with plant density of 1.66 lakh plants $\mathrm{ha}^{-1}$ ).

It is concluded that plant height, no. of monopodia and sympodial branches, no. of bolls, boll wt., seed cotton yield plant ${ }^{-1}$ were significantly higher in monsoon sowing. Growth attributes and yield attributes was also found higher in plant density of 1,11,111 plants $\mathrm{ha}^{-1}$. Fertilizer regimes of 120:60:60 NPK kg ha ${ }^{-1}$ recorded maximum plant height, no. of monopodia and sympodia, no. of bolls and seed cotton yield plant ${ }^{-1}$. Pooled seed cotton and stalk yield was significantly higher in monsoon sowing, 200\% plant density (2.22 lakh ha ${ }^{-1}$ ) and in 200\% RDF (120:60:60 NPK $\mathrm{kg} \mathrm{ha}^{-1}$ ).

\section{References}

Adare, Z. M., A. Srinivas, V. Praveen Rao, T. Ram Prakash and T. Ramesh Thatikunta, 2016. Association of weather variables with yield and yield components of cotton (Gossypium hirsutun L.) at reproductive phenophase. African Journal of Agricultural Research 11(29): 2555-2561.

Ali Liaqat., Mushtaq Ali, Mueen-ud-Din, Laila Khalid, Umm-e-kalsoom, Masood Qadir Waqar, Muhammad Anjum Ali and Muhammad Sattar, 2015. Growth and yield of two cotton varieties as affected by various planting dates. International Journal of Advanced Multidisciplinary Research 2(8): 71-80.

Ali M, Ali L, Sattar M and Ali M.A.., 2010. Response of Seed Cotton Yield to Various Plant Populations and Planting Methods. Journal of Agricultural Research 48: 163169. 
Ambati R. R. and Soniya K. Thakare, 2012. Effect of nutrient management on FUE, red leaf, fibre properties of BT hybrid cotton (Gossypium hirsutum). Indian Journal of Agronomy 57 (4): 390-396.

Aruna, E. and B. Sahadeva Reddy, 2009. Response of Bt cotton to plant geometry and nutrient combinations. Indian Journal of Agriculture Research 43 (3). 206-210.

Ban Y.G., Kumar V., Nawalkar D. P. and Narwade A.V., 2015. Influence of environment on crop phenology, thermal requirement, yield and fiber properties of cotton (Gossypium hirsutum) genotypes. Trends in Biosciences. 8(3): 768-782.

Basavenneppa, M.A., S.R. Salakinakoppa and D. P. Biradar, 2012. Productivity and profitability of Bt cotton as influenced by spacing and NPK levels in irrigated ecosystem. Journal of Cotton Research and Development. 26(1): 66-69.

Bhalerao P. D., B. R. Patil, R.N. Katkar and P. U. Ghatol, 2007. Response of deshi cotton hybrid (AKDH-5) to spacing and fertilizer levels under rainfed condition. PKV Research Journal. 31 (1): 1-3.

Bhalerao P.D., Deshmukh P.W., Nawale D.B. and Bhale V. M., 2012. Enhance productivity of cotton with high plant density system under rainfed condition. Paper presented in State level seminar on Breaking yield barriers in major field crops held at Dr. PDKV, Akola during January 6-7, PP. 114-117.

Buttar, G.S., Singh, P. and P. Kaur., 2010. Influence of date of sowing on the performance of American cotton (Gossypium hirsutum L.) genotype under semi-arid region of Punjab. Journal of Cotton Research and Development 24 (1): 56-58.

Dalvi D. G., Deosarkar D. B., Baig K. S. and Deshmukh J. D., 2015. Effect of environment on crop phenology, development and yield in $B t$ and non $B t$ cotton hybrids. In: "Future Technologies: Indian Cotton in the Next Decade" (Eds. R. S. Sangwan, S. Nimbal, M. S. Chauhan, Shiwani Mandhania and Omender Sangwan), Cotton Research and Development Association, CCS Haryana
AgriculturaI University, Hisar-125004, India. pp 32.

Damahe, A.R., S.B. Satpute and N.D. Parlawar, 2018. Growth and yield of cotton as influenced by different date of sowing and varieties. International Journal of Current Microbiology and Applied Science Special Issue-6: 2622-2628.

Deotalu, A.S., K. J. Kubde, A. N. Pasalawar, D. P. Chaudhari and V.A. Tiwari, 2013. Growth and yield of hirsutum varieties as influenced by plant spacing and fertilizer levels under rainfed condition. Annals of Plant Physiology 27 (1): 30-32.

Dhillon G. S., Chhabra K. L. and Punia S. S., 2006. Effect of crop geometry and integrated nutrient management on fibre quality and nutrient uptake by cotton crop. Journal of Cotton Research and Development, 20(2): 221-223.

Dong Hezhong, Weijiang Li, Wei Tang, Zhenhuai Li, Dongmei Zhang and Yuehua Niu, 2006. Yield, quality and leaf senescence of cotton grown at varying plant dates and plant densities in the yellow river valley of china. Field Crops Research 98: 106-115.

Hake K., Tom Burch, Lawrence Harvey, Tom Kerbyand james Supak, 1991. Plant population. In Physiology Today Newsletter of the Cotton Physiology Education Programme- National Cotton Council, Memphis February 1991, 2 (4):14.

Hake M. V., 2017. Canopy environment and morpho-phenological responses of cotton genotypes under varying population densities. M.Sc (Agri.) Thesis (Unpub.) Dr. PDKV., Akola.

Hakoomat Ali, Mohammad Naveed Afzal, Fiaz Ahmad, Shakeel Ahmad, Maqbool Akhtar, Raheel Atif, 2011. Effect of Sowing Dates, plant spacing and nitrogen application on growth and productivity on cotton crop. International Journal of Scientific \& Engineering Research 2(9): 1-6.

Hallikeri S. S., Halemani H. L., Patil V. C., Palled Y. B., Patil B. C. and Katageri I. S., 2009. Influence of sowing time and moisture regimes on growth, seed cotton yield and fibre quality of Bt-cotton. Karnataka 
Journal of Agriculture Science 22 (5): $985-$ 991.

Hargilas and Saini D. P., 2018. Performance of Bt cotton hybrids under varying plant spacing's and nutrient levels. Journal of Cotton Research and Development 32(1): 106-111.

Hebbar, K.B., M.V. Venugopalan, M. Dawale and M.R.K. Rao, 2010. Comparative performance of a rainfed cotton variety and hybrid under late sown condition. Indian Journal of Plant Physiology 15 (1): 61-64.

Hebbar, K.B., M.V. Venugopalan, M.R.K. Rao, G.D. Gadade, S. Chatterji and C.D. Mayee, 2002. Effect of sowing dates and fertilizer levels on phenology, growth and yield of cotton. Indian Journal of Plant Physiology, 7 (4), 381-383.

Hiwale, S. D., Mangala Ghanbahadur and Kharagkharate V.K.., 2016. Narrow spacing coupled with higher fertilizer doses increase cotton yield under rainfed condition. Green Farming 7(4): 893-896.

Jahedi., M.B., F.V. Vazin and M.R. Ramezani, 2013. Effect of row spacing on the yield of cotton cultivars. Cercetari Agronomice in Moldova XLVI (4): 31-38.

Jost P. H. and Cothren J. T., 2000. Growth and yield comparison of cotton planted in conventional and ultra narrow row spacing. Crop Science 40: 430-435.

Katkar, R.N., S.T. Wankhede, A.B.Turkhede and S.P. Lambe, 2005. Effect of integrated nutrient management in cotton grown on shallow soil on growth, seed cotton yield and physiochemical properties. PKV Research Journal. 29(2): 210-214.

Kharagkharate V. K., Mangala Ghanbahadur, Hiwale S., Chirde P. and Shaikh S. A., 2017. Effect of high density planting, nutrient management and moisture conservation on economics and nutrient uptake of hirsutum cotton under rainfed condition. International Journal of Pure and Applied Bioscience. 5(6): 1210-1217.

Kumar Rajesh., M.S. Bhattoo, S.S. Punia, Nabin Bhusal and Satbeer Yadav 2014. Performance of different Bt cotton (Gossypium hirsutum L.) hybrids under varying dates of sowing. Journal of Cotton Research and Development. 28(2): 263-
264.

Molin, W. T and J. A. Hugie, 2010. Effect of population density and nitrogen rate in Ultra narrow row cotton SRX Agriculture. 2010:1-5.

Naim, Ahmed M. El, Osman Abdairasol and Mahmoud F. Ahmed, 2013. Growth and yield of seed cotton response to plant spacing and weeding frequency under flood irrigation. Journal of Renewable Agriculture 1(3): 27-32

Nawaz Hamid., Nazim Hussain, Muhammad Ishaq Asif Rehmani, Azra Yasmeen and Muhammad Arif, 2016. Comparative performance of cotton cultivars under conventional and ultra-narrow row (UNR) spacing. Pure Applied Biology, 5(1): 15-25.

Nehra, P. L. and P. S. Yadav, 2012. Effect of spacing and fertilizer levels on hirsutum cotton variety $\mathrm{H} 1300$ in canal command area of North West Rajasthan. Journal of Cotton Research and Development 26 (2) 207-208.

Paslawar A. N., Deotalu A. S. and Nemade P. W., 2015. High density planting of cotton variety AKH 081 under rainfed condition of Vidarbha. Plant Archive 15 (2):1075-1077.

Pettigrew, W. T. and W. R. Meredith, Jr., 2009. seed quality and planting date effect on cotton lint yield, yield components and fiber quality. Journal of Cotton Science 13: 37-47.

Pinky Patel, Patel J. C., Vyas K. G. and Salvi Dipika, 2016. Effect of hybrids and varying planting time on growth and productivity in cotton (Gossypium hirsutum L.). The Bioscan 11 (1): 289-291.

Ram, Moola and A. N. Giri, 2006. Response of newly released cotton (Gossypium hirsutum) varieties to plant densities and fertilizer levels. Journal of Cotton Research and Development 20 (1): 85-86.

Ramzan Ali Alitabar, R. Salimbeck, O. Alishah and Seyed Abbas Ali Andarkhor, 2013. The effect of nitrogen and row spacing on growth and yield of cotton varieties. International Journal of Agriculture: Research and review. 3 (1):120-125.

Reddy, K.N., Ian C. Burke, J.Clif Boykin and J. Ray Williford, 2009. Narrow row cotton production under irrigated and non irrigated 
Environment: Plant population and lint yield. Journal of Cotton Science13: 48-55.

Rose Roche, Michel Bange, Stephen Milory and Graeme Hammer, 2003. Cotton growth in UNR system. The Australian Cotton Grower 2003

Ruth Kaggwa Asiimwe, Pedro Andrade- Sanchez and Guangyao Wang, 2013. Plant architecture influences growth and yield response of upland cotton to population density. Field Crop Research 145: 52-59.

Sankaranarayanan K., Singh Jagvir, Rajendran K., 2018. Identification of suitable high density planting system genotypes its response to different levels of fertilizers compared with Bt cotton. Journal of Cotton Research and Development 32 (1): 84-96.

Sharma Rakesh Kumar, 2004. Production potential of cotton cultivars as affected by various spacing and fertility levels. Journal of Cotton Research and Development 18 (2). 187-188.

Singh Kulvir, Harmandeep Singh, Pankaj Rathore and R. K. Gumber, 2012 ${ }^{\mathrm{b}}$. Response of desi cotton (Gossypium arboreum L.) genotypes to plant geometries and nutrient levels under irrigated conditions. Journal of Cotton Research and Development 26(1): 58-61.
Singh Kulvir, Singh Harmandeep, Rathore Pankaj, Gumber R. K. and Singh Kuldeep, 2014. Effects of nutrients and spacing on productivity of Bt cotton hybrids. Journal of Cotton Research and Development 28 (1): 45-48.

Singh, Jagvir., Shilpa Babar, Shalu Abraham, M.V. Venugopalan and G. Mujumdar, $2012^{\mathrm{a}}$. Fertilization of high density, rainfed cotton grown on vertisols of India. Better crops. 96(2): 26-28.

Stephenson, D., O., L. T. Barber and F. M. Bourland, 2011. Effect of twin row planting pattern and plant density on cotton growth, yield and fiber quality. Journal of Cotton Science, 15: 243-250.

Sweta Ganvir, Mangala Ghanbahadur and V.K. Khargkharate, 2013. Response of hirsutum cotton AKH 081 to high plant density, fertilizers and moisture conservation. Annals Plant Physiology, 27 (1): 33-37.

Zhang Dongsheng, Lizhen Zhang, Jianguo Liu, Shuo Han, Qi Wang, Jochem Evers, Jun Liu, Wopke Van der Werf and Long Li, 2014. Plant density affects light interception and yield in cotton grown as companion crop in young jujube plantations. Field Crop Research Dec.: 169: $132-139$.

\section{How to cite this article:}

Ganvir, M.M., A.P. Karunakar, V.M. Bhale, M.B. Nagdeve, V.V. Gabhane and Wanjari, S.S. 2019. Influence of Weather Variability, Plant Density and Fertilizer Regimes on Growth and Yield of Cotton under Rainfed Condition. Int.J.Curr.Microbiol.App.Sci. 8(01): 1090-1105. doi: https://doi.org/10.20546/ijcmas.2019.801.118 